\title{
A Survey on the Willingness and Influencing Factors of Farmers' Commercial Pension Insurance Participation in Heilongjiang Province
}

\author{
Dehua Zhang ${ }^{1, \text { a }}$ and Yu Zhang ${ }^{2, b}$ \\ ${ }^{1}$ Harbin University of Commerce Institute of Finance Harbin 150028 \\ ${ }^{2}$ Harbin University of Commerce Institute of Finance Harbin 150028 \\ a 445216153@qq.com, b2913418005@qq.com
}

Keywords: Commercial pension insurance; Willingness to participate; Logistic regression; Influencing factors

\begin{abstract}
Launching the willingness of farmers to participate in the participation of pension insurance will help reduce the pressure on social security funds and improve the quality of life of farmers. In this study, through the investigation of 817 farmers in Heilongjiang Province, using logistic regression analysis, the research shows that factors such as the education level, marital status, the quality of soil, and economic burden of farmers have a significant effect on the willingness to participate. Therefore, while strengthening farmers' participation in commercial pension insurance awareness, insurance companies should improve the quality of insurance services. The government should improve the agricultural subsidy system and relief system to increase farmers' coverage.
\end{abstract}

\section{Introduction}

At present, the Chinese government is making efforts to promote the "three pillars" model according to the trend of an aging population. The first pillar is the government-led basic old-age insurance system; the second pillar is the supplementary old-age insurance system, with corporate annuities and professional annuities as the mainstay; and the third pillar is commercial pension insurance, with individual savings-type pension insurance as the mainstay. The first pillar and the second pillar are mainly targeted at the employed population with a fixed work unit. The third pillar targeted at farmers is developing slowly in China and does not provide good support for the first and second pillars. In particular, Heilongjiang Province, as the country's main grain-growing area, shoulders the responsibility of ensuring national food security and stabilizing the country's grain. However, the farmers' income in this province is low and their operating risks are relatively high. With the increase of the elderly population and the intensification of air pollution, the medical expenses of the elderly population in the rural areas will also increase significantly. This will put even greater pressure on the social security funds that our government has already failed to meet.

The earliest insurance originated in Italy in the fourteenth century. In the early sixteenth century insurance-related monographs had been published. Witt (1976) believes that the supply of insurance is largely influenced by the risk appetite of policyholders, while the risk appetite of policyholders is significantly related to their income capacity and risk tolerance, so the supply of insurance varies cyclically with the policyholder's income capacity and risk tolerance. Regarding to research on insurance demand, Nguyen (2010) studied cross-sectional data of Vietnamese residents and showed that female heads of households are more inclined to purchase commercial pension insurance for the elderly and themselves, and that more highly educated communities purchase commercial pension insurance[1]. Knowles (2010) believes that families with more affluent families are more likely to purchase commercial pension insurance[1]. Arab(2015) suggested that the larger the family size, the lower the demand for personal health insurance through research on Iranian resident data[2]. Soyara (2015) found that the better the household economy, the greater the demand for insurance, and the income of household is the most important factor affecting insurance demand [3].In terms of insurance recognition factors, Tessa (2017) showed that the higher the degree of trust in life insurance is, the higher the degree of trust in life insurance is[4]. 
Therefore, it is necessary to analyze the willingness and influencing factors of the participation of the farmers' pension insurance in Heilongjiang Province. It is concluded that the results will help solve the old-age problem of the farmers and promote the implementation of the healthy strategy in China. Maintaining economic and social stability in China has important strategic and guiding significance.

\section{Materials and methods}

Variable Assignment. According to Fishbein and Ajzen's rational behavior theory TRA, people are always rational, and before making choices, they synthesize various kinds of information to consider the meaning and consequences of their actions. Ajzen proposed the theory of planned behavior on the basis of TRA. Planned behavior theory believes that behavior is caused by both behavioral intention and perceived behavioral control[5]. Behavioral intention is jointly decided by attitude, subjective norm and perceptual behavior.

The research put the decision of buying commercial pension insurance as a dependent. Buying the commercial insurance is assigned to 1 , if not the variable is assigned to 0 . The assignment of variable is showed in the table 1.

Table 1 Variable assignment table

\begin{tabular}{|c|c|c|c|c|c|c|}
\hline $\begin{array}{c}\text { Assignment } \\
\text { variable }\end{array}$ & 0 & 1 & 2 & 3 & 4 & 5 \\
\hline $\begin{array}{l}\text { The level of } \\
\text { education }\end{array}$ & $\begin{array}{c}\text { Elementary } \\
\text { school and } \\
\text { below }\end{array}$ & $\begin{array}{c}\text { Junior high } \\
\text { school }\end{array}$ & $\begin{array}{c}\text { Senior high } \\
\text { school }\end{array}$ & $\begin{array}{l}\text { Bachelor } \\
\text { degree and } \\
\text { above }\end{array}$ & & \\
\hline Methods of living & & Living alone & Cohabitation & & & \\
\hline Marital Status & & Unmarried & $\begin{array}{c}\text { Divorced and } \\
\text { Widowed }\end{array}$ & Married & & \\
\hline Burden & & No & Patients & Students & $\begin{array}{l}\text { Patients and } \\
\text { Students }\end{array}$ & \\
\hline $\begin{array}{l}\text { Quality of soil } \\
\text { The expectation } \\
\text { about the old life }\end{array}$ & & $\begin{array}{c}\text { poor } \\
\text { Worried }\end{array}$ & $\begin{array}{l}\text { general } \\
\text { No worry }\end{array}$ & good & & \\
\hline
\end{tabular}

Survey Method and Questionnaire Recovery. The study investigated four areas, including Qiqihar, Daqing, Jiamusi, and Jixi. Use random sampling and questionnaires to collect data, A total of 832 questionnaires were distributed, remove 14 questionnaires that are seriously inconsistent with reality and 817 valid questionnaires, the effective rate is $98.31 \%$, which meets the research requirements.

Based on past research and availability of data, this study divides the factors that may affect the willingness of farmers to participate in commercial pension insurance into seven categories: (1) Personal characteristics, which mainly include: gender, age, education level, living style, marital status and health status(2)The family characteristics include: the number of family members, the number of children, the economic situation of relatives and the proportion of stable staff(3)Factors of economic burden, including whether there are patients and students attending school(4)Work occupation factors, including income, planting species, land size and land quality(5)Insurance cognition factors mainly include understanding of commercial pension insurance, impressions of insurance sales personnel, purchase experience of commercial pension insurance, and purchase satisfaction of commercial pension insurance(6)Insurance substitution factors mainly include whether to pay back social security, whether to participate in social pension insurance and whether to purchase new rural cooperative medical insurance(7)Risk appetite factors, mainly including pension expectations.

The number of effective people in this study surveyed totaled 817 people, of whom 495 were willing to participate in commercial pension insurance, accounting for $60.6 \%$, and 322 people were not willing to participate, accounting for $39.4 \%$. It shows that most farmers are relatively satisfied with commercial pension insurance, and that the existing pension system and income cannot fully cover the expenditures of the old age, so they tend to provide more protection for their own old age 
by participating in commercial pension insurance. In terms of education, the education level of the farmers is generally low. The primary school and below farmers account for $51 \%$ of the sample size of the survey, accounting for about half, the proportion of undergraduate and above education is the lowest, which is $6.9 \% .89 .4 \%$ of farmers choose to live together. Among the marital status variables, the surveyed farmers have the largest proportion of married people, which is $65.9 \%$. Some 53.7 people think that their health status is normal. According to the family characteristics variable, the largest proportion of households with 4-6 people is $66 \%$, and the relative status of farmers is generally good, accounting for $84 \%$, and there are only a small number of stable workers in the farmers, and only one farmer's family. The proportion of stable staff in the middle is $100 \%$, reflecting the instability of farmers' income. Among the variables of the economic burden, $62.8 \%$ of the farmers' families have children who are attending school, and at the same time there are patients who need care, indicating that most of the farmers' economic burden is heavy, which will have an important impact on their willingness to participate in commercial pension insurance. Among the income variables, more than half of the farmers' income is between 2 and 4 million. Farmers who grow non-economic crops account for a relatively large proportion, accounting for $76.2 \%$. In terms of land quality, only $18.5 \%$ of farmers' land is in good condition, it shows that the income of the farmers is not sustainable and it is difficult to afford the pension needs.

\section{Results}

This study will be willing to participate in the commercial pension insurance is assigned a value of 1 , unwilling to participate in commercial pension insurance is assigned a value of 0 , for the characteristics of binary data, logistic regression model was chosen for analysis. The model is as follows.

$$
P_{i}=F\left(\beta_{0+} \sum_{j=1}^{k} \beta_{j} X_{i j}\right)
$$

$$
\left.\mathrm{Pi}=\frac{1}{1+\exp \left[-\left(\beta_{0}+\sum_{\mathrm{j}=1}^{\mathrm{k}} \beta_{\mathrm{j}} \mathrm{X}_{\mathrm{ij}}\right)\right.}\right]
$$

Where Pi denotes the probability of farmers participating in commercial pension insurance, $\mathrm{i}$ denotes the number of farmers; $i$ denotes the regression coefficient of the factor, $j$ denotes the number of the influencing factors; $\mathrm{Xij}$ is the independent variable, and denotes the $\mathrm{jth}$ influence factor of the $\mathrm{i}$-th farmer; 0 denotes the regression distance.

Logistic regression was used to screen out the independent variables, and the model of participation in commercial endowment insurance was derived. as shown in table 2.

\begin{tabular}{|c|c|c|c|c|c|c|}
\hline & B & Standard error & Wald & $\begin{array}{l}\text { Degree of } \\
\text { freedom }\end{array}$ & Significant & $\operatorname{Exp}(B)$ \\
\hline Education $\mathrm{X}_{1}$ & .209 & .113 & 3.439 & 1 & .006 & 1.233 \\
\hline LiveX ${ }_{2}$ & -.990 & .308 & 10.352 & 1 & .001 & .372 \\
\hline Marriage $_{3}$ & .442 & .127 & 12.045 & 1 & .001 & 1.556 \\
\hline $\begin{array}{l}\text { Patient or } \\
\text { student } \mathrm{X}_{4}\end{array}$ & .228 & .076 & 8.918 & 1 & .003 & 1.256 \\
\hline $\begin{array}{c}\text { Land } \\
\text { Quality } X_{5}\end{array}$ & -.323 & .158 & 4.186 & 1 & .041 & .724 \\
\hline $\begin{array}{c}\text { Pension }_{6} \\
\text { constant }\end{array}$ & $\begin{array}{l}-.229 \\
-1.027\end{array}$ & $\begin{array}{l}.177 \\
1.373\end{array}$ & $\begin{array}{l}1.681 \\
.559\end{array}$ & $\begin{array}{l}1 \\
1\end{array}$ & $\begin{array}{l}.195 \\
.454\end{array}$ & $\begin{array}{l}.795 \\
.358\end{array}$ \\
\hline $\begin{array}{l}\text { Model accuracy } \\
\text { rate }\end{array}$ & & & & & & 71.5 \\
\hline
\end{tabular}

Table 2 Variable regression analysis results

According to the analysis of variable regression results, the regression equation is 


$$
\mathrm{Y}=0.209 X_{3}-0.990 X_{6}+0.442 X_{7}+0.228 X_{8}-0.323 X_{14}+-0.229 X_{23}-1.027 .
$$

The level of significance of the education level variable is $0.006<0.05$ and the coefficient is 0.209 , indicating that the cultural level factor has a significant positive effect on the willingness of farmers to participate in the commercial pension insurance. This is because with the increase in the number of years of education, farmers have a deeper understanding of insurance knowledge and the concept of pension is more advanced. The coefficient of dwelling mode of living was -0.990 , and the level of significance was $0.001<0.05$, which met the level of significance. It shows that farmers living alone are more inclined to participate in commercial pension insurance, and farmers living alone have a relatively low sense of security. The significant level of marital status variables is $0.001<0.01$, which means that married farmers are more inclined to purchase commercial pension insurance because married farmers generally have a certain economic basis and are able to participate in commercial pension insurance. Farmers with a heavier family economic burden tend to purchase commercial pension insurance. At the same time, farmers with sick children and school children will become the most important audience group for commercial pension insurance. The economic burden variable meets the requirements at a $5 \%$ level of significance. Land quality has a negative impact on the willingness to participate. The lower the land quality, the worse the sustainable production capacity. Therefore, farmers are more inclined to participate in commercial pension insurance.

\section{Conclusions}

In this study, farmers' survey data from four cities in Heilongjiang Province were used to analyze the seven factors of personal characteristics, family characteristics, economic burden factors, and occupation factors through logistic regression models to examine the willingness of farmers to participate in commercial pension insurance. Some conclusions as follows.

The degree of education and marital status have a significant positive impact on the willingness to participate. The higher the degree of education, the greater the likelihood of people participating in commercial pension insurance. Married farmers are more willing to protect old age through commercial pension insurance. The lifestyle variables are negatively related to participation factors, and farmers living alone are more likely to participate in commercial pension insurance. Farmers with a heavier family economic burden are more likely to participate in commercial insurance. With the reduction of sustainable land production capacity, farmers' willingness to participate in commercial pension insurance will increase.

The conclusion of this study has important policy significance. First of all, the government should introduce relevant policies, focus on the farmers living alone, give them corresponding subsidies and tax incentives, reduce their economic burden, encourage farmers living alone to participate in commercial pension insurance, and at the same time reduce the financial pressure on our government. The influence of health status on participation intention is not significant. From another aspect, the main obstacle for farmers to consider commercial pension insurance is economic pressure rather than their own health status. The relevant departments should work with insurance companies to formulate corresponding insurance systems and try to exclude farmers. The economic barriers to buying commercial pension insurance.

Second, improve the agricultural subsidy system and relief system. This study shows that the demand for commercial old-age insurance for farmers with poor land quality is even stronger. The local government should improve the system of agricultural subsidies targeted specifically, promote the sustainable development of agriculture, and provide corresponding relief assistance. Improve the living standards of farmers, improve business practices, help farmers seek more sources of income, encourage farmers to participate in commercial pension insurance, and increase the coverage of endowment insurance.

Finally, insurers need to develop new marketing strategies and innovate insurance varieties. According to the needs of this special group of farmers, the quality of insurance workers will be improved and the pace of commercial pension insurance will be promoted in rural areas. According to farmers with different characteristics, differentiated services will be adopted to effectively meet 
the old-age needs of farmers, At the same time, according to the state of the land, the preferential policies for farmers' insurance shall be given to achieve the unity of social benefits and economic benefits.

\section{Acknowledgements}

First of all, I would like to express my gratitude to all Projects which helped my thesis during the writing of this thesis, including 17JYC144, UNPYSCT-2017203, 17XN050, whose granted financial support.

Second, I gratefully acknowledge the help of my supervisor Mr.zhang, who has offered me valuable suggestions in the academic studies. In the preparation of this thesis, he has spent much time reading through each draft and provided me with inspiring advice. Without his patient instruction, insightful criticism and expert guidance, the completion of this thesis would not have been possible.

Last, I should finally like to express my gratitude to my beloved parents who have always been helping me out of difficulties and supporting without a word of complaint.

\section{References}

[1] N.K. James: Social Science \& Medicine, Vol. 71 (12) No.3, p.2074.

[2] E.S. Arab and M.E. J: The Eurasian Journal of Medicine, Vol. 48 (03) No.10, p.172.

[3] M.S. Nouraei : Global Journal of Health Science, Vol. 14 (02) No.2, p.285.

[4] T. Oraro and G.Y. Atohmbom: Health Policy and Planning,Vol. 24 (12) No.62, p.123.

[5] Machnes Y. European Journal of Health Economics, Vol.7 (4) No.33, p.265.

[6] Peng L, Fang W. Heterogeneity of Inferring Reputation of Cooperative Behaviors for the Prisoners' Dilemma Game [J]. Physica A: Statistical Mechanics and its Applications, 2015, 433: 367-378. 